\title{
FGF3 Gene Mutation
}

National Cancer Institute

\section{Source}

National Cancer Institute. FGF3 Gene Mutation. NCI Thesaurus. Code C148113.

A change in the nucleotide sequence of the FGF3 gene. 